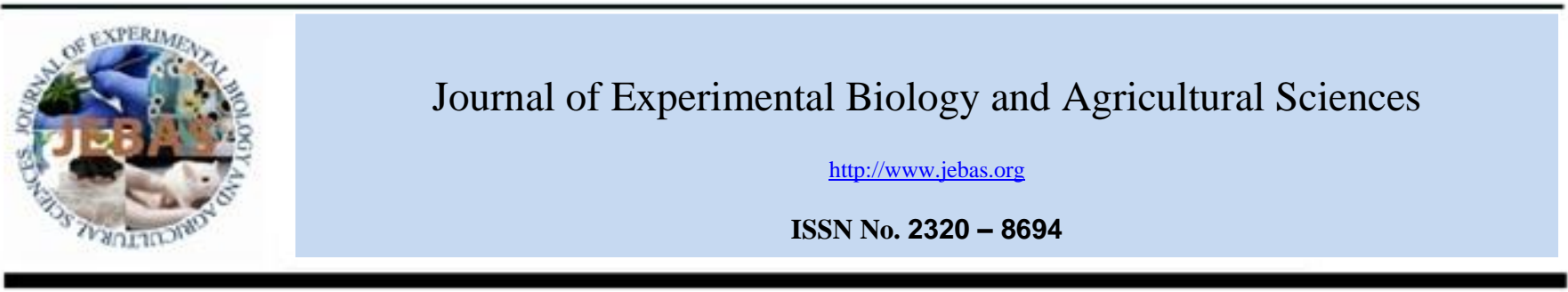

\title{
LYME BORRELIOSIS IN THE HORSE:
}

\section{A MINI-REVIEW}

\section{J.H. van der Kolk ${ }^{*}$}

Division of Clinical Veterinary Medicine, Swiss Institute for Equine Medicine (ISME), Vetsuisse Faculty, ALP Haras, University of Bern, Länggassstrabe 124, 3012 Bern, Switzerland

Received - November 06, 2016; Revision - November 20, 2016; Accepted - December 05, 2016

Available Online - December 17, 2016

DOI: http://dx.doi.org/10.18006/2016.4(Spl-4-EHIDZ).S196.S202

\section{KEYWORDS}

Lyme borreliosis

Horse

\section{* Corresponding author}

E-mail: johannes.vanderkolk@ vetsuisse.unibe.ch (J.H. van der Kolk)

Peer review under responsibility of Journal of Experimental Biology and Agricultural Sciences.

Production and Hosting by Horizon Publisher India [HPI] (http://www.horizonpublisherindia.in/).

All rights reserved

\begin{abstract}
Lyme borreliosis is a multisystemic tick borne disease (also called Lyme disease in humans) which is caused by the Borrelia burgdorferi sensu lato species complex. It is a thin, elongated Gram-negative bacterium and exhibiting motility with flagellar projections. Affected animals mainly show cranial or peripheral neuropathies and uveitis as the more commonly seen extraneural manifestation. Serological evidences confirm its higher occurrence in elderly horses than young ones. Although, incidence of equine Lyme borreliosis is low, its diagnosis is a real challenge. As no indisputable test exists for detecting antibodies to B. burgdorferi, histopathology remains the gold standard and might reveal vascular sclerosis and pleocellular inflammatory infiltrates in neural tissue. Despite antibiotic treatment clinical signs might progress or recur. This review converses with the disease etiology, pathobiology in brief and its mangment from publich health point of view.
\end{abstract}

All the article published by Journal of Experimental Biology and Agricultural Sciences is licensed under a Creative Commons Attribution-NonCommercial 4.0 International License Based on a work at www.jebas.org.

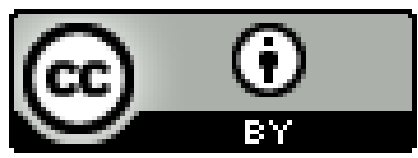




\section{Introduction}

Lyme borreliosis caused by the Borrelia burgdorferi sensu lato species complex, is a multisystemic tickborne disease (also called Lyme disease in humans). About a century back, Afzelius was the first to notice expanding skin lesion in a human patient, and named it as erythema migrans, which has now become clear to be as the initial skin manifestation of Lyme disease. Subsequently, in 1976 Burgdorfer and his associates first time reported the etiologic agent of this disease and also performed an epidemiological evaluation on a cluster of children suffering with arthritis in the city Old Lyme, Connecticut, USA. This became the first report on Lyme disease (Mast \& Burrows 1976; Steere et al., 1977; Burgdorfer et al., 1982; Butler et al., 2005; Steere 2006; Staneck et al., 2012).

Hitherto studies have revealed geographical restiction of this bacteria, as in Europian countries, five genospecies of $B$. burgdorferi s.l. have been found to affect humans, namely $B$. afzelii, B. burgdorferi s.s., B. garinii, B. spielmanii and $B$. Bavariensis. Among these, the first three are the predominant species. While in North America, B. burgdorferi s.s. is the only species that is pathogenic for humans. In Asian region, $B$. garinii is more commonly reported (Staneck et al., 2012).

In the equine species, diagnosis of Lyme borreliosis remains a challenge like in other species. As a consequence, the question if Lyme borreliosis in horses is overdiagnosed remains valid even to date (Bartol, 2013). This review converses with the recent information available on Lyme borreliosisin the horse.

\section{Etiology}

Borrelia sps. are gram-negative, flagellated, thin and elongated motile bacteria. This bacterium possess 21 plasmids (nine circular and 12 linear), which is the largest number of plasmids to be found in any known bacterium. Moreover, it also shows genetic complexity with at least 132 functioning genes, intracellular localisation, immune evasion, and auto-regulation, which makes this spirochaete a formidable infectious pathogen (Qiu et al., 2004; Stricker et al., 2005).These bacteria belong to the phylum Spirochaetes and are grouped in the B. burgdorferi s.l. genospecies complex that contains at least 20 proposed genospecies such as B. afzelii, B. garinii, B. burgdorferi sensu stricto, B. andersoni, B. japonica, B. lusitaniae, B. sinica, $B$. tanuki, B. turdii, B. valaisiana, and B. bissettii (Stanek et al., 2004; Wang et al., 1999; Becker et al., 2016). Phylogenetically all these genospecies are classifed into two major clades: one that represents Europian and Asian species and another consists of species found in North America and Europe. Furthermore, the two groups in the "American" cluster $(B$. burgdorferi s.s. and B. Bissettiae) occur in Europe as well as in North America. This raises concern over the common ancestor of this cluster whether it originated in North America or Europe (Becker et al., 2016).
In Austria, B. afzelii is the predominant genospecies in clinically normal horses (Muller et al., 2002). Lately, $B$. lusitaniae infection has been noticed in horses in Italy (Veronesi et al., 2012).

\section{Epidemiology}

In Europe, Ixodes ricinus is the main vector of B. burgdorferi s.l. in comparison to black-legged ticks (Ixodes scapularis) which is more common in the USA. The small rodents also act as reservoirs (Gern et al., 1998, Humair et al., 1998). Additionally, birds have been found to play a major role in the ecology of Lyme borreliosis, where ticks have been transported over large distances and across geographical barriers by avian hosts (Humair, 2002). To note, particular vector adaptations determine the geographic distribution range of genospecies (Becker et al., 2016).

It has been noticed that B. burgdorferi s.s. may persist in clinically healthy horses (Chang et al., 2000). The seroprevalence of Lyme borreliosis in horses varies with geographical areas. In some areas of the north-eastern USA it is about 33-50\% (Funk et al., 2016; Magnarelli et al., 2000), 9.8-42.8\% in Brazil (Basile et al., 2016), 31-48\% in France (Maurizi et al., 2010), 29\% in Denmark (Hansen et al., 2010), $26 \%$ in Poland (Stefanciková et al., 2008), 24\% in Italy (Ebani et al., 2012), 6\% in Turkey (Bhide et al., 2008), and 5.5\% in Korea (Lee et al., 2016). Older horses are more prone for positive test response than younger ones (Ebani et al., 2012; Funk et al., 2016). Of note, no significant differences in the mean seroprevalence were observed in the respective years in Italy (Ebani et al., 2012). It has been indicated that the majority of horses that were positive on initial testing did not have a different test result 5-17 months later (Funk et al., 2016). Recently, Lee et al. (2016) showed statistically significant differences according to breed and region where variances might be attributed to the ecology of vector ticks and climate conditions.

The presence of viable $B$. burgdorferi spirochetes observed in clinically healthy horse's urine in an endemic region (Manion et al., 1998) has raised concern whether non-tick transmission of this bacterium may occur by direct urine/mucosal contact (Butler et al., 2005).

\section{Pathophysiology}

The attachment of an outer-coat protein (OspA) displayed on the lumenal side of the gut of ticks (like black-legged ticks Ixodes scapularis or Ixodes ricinus) to a receptor (TROSPA) favours $B$. burgdorferi to persist in the gut and avoid elimination (Pal et al., 2004). The infection may be acquired through larvae or nymphs feeding on small to medium sized wild animals harbouring the B. burgdorferi as reservoir. Adult ticks have been found to only engorge on larger animals (deer, sheep, cows and horses). Of the note, B. burgdorferi s.l. DNA has been more commonly detected in female ticks, followed by 
nymphs and larvae, and least in adult male ticks (Wodecka, 2003). After the attachment of ticks to a host, the spirochetes present in the midgut of ticks move through the midgut wall and haemocoel, reach the salivary glands and get inoculated with the saliva of ticks into the host 2-3 days after attachment (Piesman et al., 1987). On few occasions, inoculation may occur earlier if spirochetes are already present in the salivary glands of the infected tick (Alekseev et al., 1995). Though, for proper B. burgdorferi transmission to occur an infected tick must attach for at least 24 hours on the animal (Thanassi \& Schoen 2000), its transmission to the host has been seen to occur as early as 18 hours after attachment (Alekseev et al., 1995). Concurrent infection with other tick-borne pathogens like Anaplasma phagocytophilum (Persing 1997) and Theileria equi (Basile et al., 2015) can occur.

The predominant migration of $B$. burgdorferi within connective tissues may provide protection to this bacterium from humoral antibodies (Divers et al., 2001).

\section{Clinical Presentation}

Of the 16 equine cases with histologically confirmed Lyme borreliosis recently reviewed, 12 were geldings, while the remainder was mares. Breeds included 6 Thoroughbreds, 2 Paints, 2 Ponies, 2 Quarter Horses, and one each of Haflinger, Arabian, and Morgan. The breed was not known in one of the cases studied. The horses were not vaccinated against Borrelia (Johnstone et al., 2016).

Incubation period of this bacterium in the equine species has not been established yet. Clinical signs in horses attributed to B. burgdorferi include low grade fever and lethargy (Burgess \& Mattison 1987b; Magnarelli et al., 1988; Johnstone et al., 2016), weight loss (Johnstone et al., 2016), changes in behavior (Johnstone et al., 2016), dysphagia (Johnstone et al., 2016), lameness (Browning et al., 1993), arthritis (Burgess et al., 1986; Hahn et al., 1996; Passamonti et al., 2015; Johnstone et al., 2016), neck stiffness (Johnstone et al., 2016), episodic respiratory distress (Johnstone et al., 2016), muscle tenderness (Divers et al., 2003) and fasciculations (Johnstone et al., 2016), anterior uveitis (Burgess et al., 1986; Hahn et al., 1996; Johnstone et al., 2016), cranial nerve deficits (Johnstone et al., 2016), ataxia (Johnstone et al., 2016), meningo-encephalitis (Burgess \& Mattison 1987b; James et al., 2010; Imai et al., 2011), abortion (Sorensen et al., 1990), cardiac arrhythmias (Johnstone et al., 2016) and foal mortality (Burgess et al., 1987a). Ataxia was characterized by general proprioceptive deficits and was frequently reported in conjunction with limb paresis. Signs of generalized lower motor neuron weakness, facial nerve deficits with paresis or muscle fasciculations have been observed less frequently. Dysphagia, tongue paresis and fasciculations are also clinically evident. The variation reported in presenting complaints reflects the multisystemic nature of Lyme borreliosis. Uveitis has been reported to be the most frequent extraneural manifestation of Borrelia infection (Johnstone et al., 2016).
The variation of the clinical presentation in B. burgdorferi infected horses might be unapparent due to co-infection with pathogens like A. phagocytophylum. Such variation might also occur due to infection with different genospecies of $B$. burgdorferi as has been seen in case of human beings (Butler et al., 2005).

\section{Differential Diagnosis}

The differential diagnosis is large not only due to the great variety in clinical signs but also associated with different $B$. burgdorferi genospecies and possible co-infection.

\section{Diagnosis}

The diagnosis of borreliosis in horses as well as in other species remains a challenge as persistent $B$. burgdorferi infections without any clinical symptoms have been documented in horses too (Chang et al., 2000). Antibodies can be detected at 5-6 weeks in Ponies exposed to ticks infected with $B$. burgdorferi, with the highest antibody levels induced at 3 months after exposure (Chang et al., 2000). Preference might be given to culture of $B$. burgdorferi from equine skin biopsies (Chang et al., 2000) combined with a two-step serology protocol (ELISA or IFAT supplemented by protein immunoblotting like Western blot or reverse line blot) (Trevejo et al., 1999; Magnarelli et al., 2000; Butler et al., 2005).

The development and validation of a new fluorescent beadbased multiplex assay for the detection of antibodies to outer surface protein A (OspA), OspC and OspF antigens of $B$. burgdorferi in horse serum has been reported. This assay has improved analytical and diagnostic sensitivities compared to Western blot analysis. Multiplex analysis is a valuable quantitative tool that simultaneously detects antibodies indicative for natural infection with and/or vaccination against the Lyme pathogen (Wagner et al., 2011).

Commercial C6 testing identified most infected horses but also resulted in false positive and false negative interpretations (Johnson et al., 2008; Wagner et al., 2013; Schvartz et al., 2015b). A recent study indicated that the available serologic tests (a point-of-care C6 enzyme-linked immunosorbent assay (ELISA), an whole-cell IFAT, an ELISA confirmed with Western blot, and the Lyme multiplex assay for antibodies against $B$. burgdorferi) all lacked agreement when used to assess the exposure to B. burgdorferi of horses from a lowprevalence population. Samples found positive by whole-cell IFAT and Lyme multiplex assay, detecting antibodies against Osp C during early antibody responses, could yield negative results by ELISA. The differences between the diagnostic tests owes to varying sensitivities for Osp C antibodies detection, supported by the low anti-Osp C titers in the Lyme multiplex assay. Caution against the use of serologic "screening" in the absence of clinical suspicion has been advocated accordingly (Schvartz et al., 2015a). 
Overall, $94 \%$ of the suspected horse samples were seropositive by luciferase immunoprecipitation systems (LIPS) test, and heat map analysis revealed that seropositive samples often were immunoreactive with at least two of the three antigens (against the synthetic VOVO antigen, comprising repeated immunodominant C6 epitopes as well as OspC immunodominant epitopes). These results suggest that LIPS tests employing multiple recombinant antigens offer a promising approach for the evaluation of antibody responses in Lyme borreliosis (Burbelo et al., 2011).

Due to limitations of false negative results of serum tests during $B$. burgdorferi associated uveitis and their failure to identify an active infection, a combination of cytologic assessment, antibody, and/or PCR testing of ocular fluids has been suggested to be worthwhile when the clinical suspicion is high for Lyme uveitis.

Of note, horses treated with antibiotics revealed a decline in ELISA titres as compared to control horses $(\mathrm{P} \leq 0.05)$ while the untreated horses showed increased ELISA titres $(\mathrm{OR}=0.5$; 95\% C.I. $=0.3-0.9$ ). Such decline in ELISA titres was low in comparison to the previously reported results in experimentally infected and treated ponies. Horses exposed in the field with $B$. burgdorferi having high ELISA values when treated with either oxytetracycline or doxycycline may show only a small decline in ELISA values (Divers et al., 2012).

It should be realized that negative serology and normal CSF analysis do not exclude the diagnosis of Lyme borreliosis and it has been stated that histopathology might represent the most definitive test for borreliosis in horses. However, when presented with a horse displaying ataxia, cranial nerve deficits, and weight loss, with historic or current evidence of uveitis, collapse, or dysphagia, one should consider Lyme borreliosis regardless of CSF analysis or serological results (Johnstone et al., 2016).

\section{Pathology}

Duration of disease before death has been observed to range from 2 to 730 days with a median of 120 days (IQR 33-180 days) (Johnstone et al., 2016). Spirochetes can be visualized in affected tissues of the horses with Lyme borreliosis by Steiner silver impregnation and immunohistochemistry, predominantly within the dense collagenous tissue of the dura mater and leptomeninges (Imai et al., 2011). Leptomeningitis, lymphohistiocytic leptomeningeal vasculitis, cranial neuritis, and peripheral radiculoneuritis with Wallerian degeneration are the lesions observed during histopathology, which are consistent with a diagnosis of neuroborreliosis (James et al., 2010; Johnstone et al., 2016).

In comparison, lesions in B. burgdorferi s.s. infected ponies have been reported to be limited to the skin, observed as perivascular and perineural lymphohistiocytic aggregates in the superficial and deep dermis (Chang et al., 2000). B. burgdorferi PCR of nervous tissue obtained positive results in
5/10 horses with histologically confirmed Lyme borreliosis. Of the 5 cases that had a negative PCR, 4 were positive with Warthin-Starry stain and one showed an indication of intrathecal antibody production (Johnstone et al., 2016). The distribution and histologic features including vascular sclerosis (indicating chronicity) and pleocellular inflammatory infiltrates present in horses with histologically confirmed Lyme borreliosis are rather characteristic (Johnstone et al., 2016).

\section{Management/Treatment (including prognosis)}

In comparison to oral administration of doxycycline or parenteral sodium ceftiofur, tetracycline @ $6.6 \mathrm{mg} / \mathrm{kg} \mathrm{BW} \mathrm{IV}$ bid for 3 weeks has been found to be superior for treatment of B. burgdorferi infected ponies (Divers et al 2003). Besides, avoiding tick-infested areas as well as careful grooming of the horse for early removal of ticks are the best preventive measures. For prevention of tick-infestation, various kind of insecticidal sprays can be used but most of these have not been approved for horses and also their efficacy is unproven yet (Butler et al., 2005). However, the use of canine tick sprays on horses till so far has not revealed any adverse effects (Divers et al., 2001).

Of interest, a 12-year-old thoroughbred horse with $B$. burgdorferi infection responded well to doxycycline treatment (10 mg/kg BW PO q $12 \mathrm{~h}$ for 60 days) and returned to normal exercise. However, the horse was found to again develop a stiff neck and rapidly progressive neurologic deficits along with severe ataxia and vestibular deficits after 60 days of treatment. The condition of the horse got deteriorated rapidly despite administering IV oxytetracycline, and it was euthanatized (James et al., 2010).

Eight horses out of sixteen horses with histologically confirmed Lyme borreliosis received antibiotic treatment, including doxycycline, minocycline, oxytetracycline, or ceftiofur. In these cases, clinical signs either continued to progress or, despite an initial improvement, plateaued or showed recurrence and subsequent progression (Johnstone et al., 2016).

Of importance, persistently high serum titres observed after treatment of Lyme disease in horses, without the presence of clinical signs, may not be a reason to follow more prolonged treatment (Divers et al., 2012).

\section{Public Health Significance}

Lyme borreliosis is regarded as an important tick borne zoonosis although the equine species is not considered as a main reservoir for human infection. However, the presence of viable B. burgdorferi spirochetes has been observed in urine of clinically healthy horses (Manion et al., 1998). Lyme borreliosis is the most common human tick-transmitted disease in the northern hemisphere. A complete presentation of the disease is an extremely unusual observation in which a skin lesion results from a tick bite and is followed by heart and 
nervous system involvement, and later on by arthritis. Late involvement of eye, nervous system, joints, and skin can also occur. The only sign that enables a reliable clinical diagnosis of Lyme borreliosis in humans is erythema migrans (Stanek et al., 2004).

\section{Conflict of interest}

Authors would hereby like to declare that there is no conflict of interests that could possibly arise.

\section{References}

Alekseev AN, Arumova EA, Vasilieva IS (1995) Borrelia burgdorferi sensu lato in female cement plug of Ixodes persulcatus ticks (Acari, Ixodidae). Experimental and Applied Acarology 19: 519-522.

Bartol J (2013) Is Lyme disease overdiagnosed in horses? Equine Veterinary Journal 45: 529-30.

Basile RC, Rivera GG, Del Rio LA, de Bonis TC, do Amaral GP, Giangrecco E, Ferraz G, Yoshinari NH, Canola PA, Queiroz Neto A (2015) Anaphylactoid reaction caused by sodium ceftriaxone in two horses experimentally infected by Borrelia burgdorferi. BMC Veterinary Research 11: 197.

Basile RC, Yoshinari NH, Mantovani E, Bonoldi VN, Macoris DD, Queiroz-Neto A (2016) Brazilian borreliosis with special emphasis on humans and horses. Brazilian Journal of Microbiology. pii: S1517-8382(16)30902-9. doi: 10.1016/j.bjm.2016.09.005.

Becker NS Margos G, Blum H, Krebs S, Graf A, Lane RS, Castillo-Ramírez S, Sing A, Fingerle V (2016) Recurrent evolution of host and vector association in bacteria of the Borrelia burgdorferi sensu lato species complex. BMC Genomics 17:734.

Bhide M, Yilmaz Z, Golcu E, Torun S, Mikula I (2008) Seroprevalence of anti-Borrelia burgdorferi antibodies in dogs and horses in Turkey. Annals of Agricultural and Environmental Medicine 15: 85-90.

Browning A, Carter SD, Barnes A, May C, Bennett D (1993) Lameness associated with Borrelia burgdorferi infection in the horse. Veterinary Record 132: 610-611.

Burbelo PD, Bren KE, Ching KH, Coleman A, Yang X, Kariu T, Iadarola MJ, Pal U (2011) Antibody profiling of Borrelia burgdorferi infection in horses. Clinical and Vaccine Immunology 18: 1562-1567.

Burgdorfer W, Barbour AG, Hayes SF, Benach JL, Grunwaldt E, Davis JP (1982) Lyme disease-a tick-borne spirochetosis? Science 216 : 1317-1319.
Burgess EC, Gillette D, Pickett JP (1986) Arthritis and panuveitis as manifestations of Borrelia burgdorferi infection in a Wisconsin pony. Journal of the American Veterinary Medical Association 189: 1340-1342.

Burgess EC, Genchon-Fitzpatrick A, Mattison M (1987a) Foal mortality associated with natural infection of pregnant mares with Borrelia burgdorferi (abstract). 5th International Conference of Equine Infectious Diseases pp: 217.

Burgess EC, Mattison M (1987b) Encephalitis associated with Borrelia burgdorferi infection in a horse. Journal of the American Veterinary Medical Association 191: 1457-1458.

Butler CM, Houwers DJ, Jongejan F, Kolk JH van der (2005) Borrelia burgdorferi infections with special reference to horses. A review. Veterinary Quarterly 27 : 146-156.

Chang YF, Novosol V, McDonough SP, Chang CF, Jacobson RH, Divers TJ, Quimby FW, Shin S, Lein DH (2003) Experimental infection of ponies with Borrelia burgdorferi by exposure to Ixodid ticks. Veterinary Pathology 37: 68-76.

Divers TJ, Chang YF, Jacobson RH, McDonough SP (2001) Lyme disease in horses. Compendium on Continuing Education for the Practicing Veterinarian 23: 375-380.

Divers TJ, Chang YF, McDonough PL (2003) Equine Lyme disease: a review of experimental disease production, treatment efficacy, and vaccine protection. 49th Annual Convention of the American Association of Equine Practitioners, November 2003, New Orleans, Louisiana, USA.

Divers TJ, Grice AL, Mohammed HO, Glaser AL, Wagner B (2012) Changes in Borrelia burgdorferi ELISA antibody over time in both antibiotic treated and untreated horses. Acta Veterinaria Hungarica 60 : 421-429.

Ebani VV, Bertelloni F, Pinzauti P, Cerri D (2012) Seroprevalence of Leptospira spp. and Borrelia burgdorferi sensu lato in Italian horses. Annals of Agricultural and Environmental Medicine 19 : 237-240.

Funk RA, Pleasant RS, Witonsky SG, Reeder DS, Werre SR, Hodgson DR (2016) Seroprevalence of Borrelia burgdorferi in Horses Presented for Coggins Testing in Southwest Virginia and Change in Positive Test Results Approximately 1 Year Later. Journal of Veterinary Internal Medicine 30 : 1300-1304.

Gern L, Estrada-Pena A, Frandsen F, Gray JS, Jaenson TGT, Jongejan F, Kahl O, Korenberg E, Mehl R, Nuttall PA (1998) European reservoir hosts of Borrelia burgdorferi sensu lato. Zentralblatt für Bakteriologie 287: 196-204.

Hahn CN, Mayhew IG, Whitwell KE, Smith KC, Carey D, Carter SD, Read RA (1996) A possible case of Lyme borreliosis in a horse in the UK. Equine Veterinary Journal 28:84-88 
Hansen MG, Christoffersen M, Thuesen LR, Petersen MR, Bojesen AM (2010) Seroprevalence of Borrelia burgdorferi sensu lato and Anaplasma phagocytophilum in Danish horses. Acta Veterinaria Scandinavica 52: 49

Humair PF, Rais O, Gern L (1999) Transmission of Borrelia afzelii from Apodemus mice and Clethrionomys voles to Ixodes ricinus ticks: differential transmission pattern and overwintering maintenance. Parasitology 118: 33-42.

Humair PF (2002) Birds and Borrelia. International Journal of Medical Microbiology 291: 70-74.

Imai DM, Barr BC, Daft B, Bertone JJ, Feng S, Hodzic E, Johnston JM, Olsen KJ, Barthold SW (2011) Lyme neuroborreliosis in 2 horses. Veterinary Pathology $48: 1151$ 1157.

James FM, Engiles JB, Beech J (2010) Meningitis, cranial neuritis, and radiculoneuritis associated with Borrelia burgdorferi infection in a horse. Journal of American Veterinary Medical Association 237: 1180-1185.

Johnson AL, Divers TJ, Chang YF (2008) Validation of an inclinic enzyme-linked immunosorbent assay kit for diagnosis of Borrelia burgdorferi infection in horses. Journal of Veterinary Diagnostic Investigation 20: 321-324.

Johnstone LK, Engiles JB, Aceto H, Buechner-Maxwell V, Divers T, Gardner R, Levine R, Scherrer N, Tewari D, Tomlinson J, Johnson AL (2016) Retrospective Evaluation of Horses Diagnosed with Neuroborreliosis on Postmortem Examination: 16 Cases (2004-2015). Journal of Veterinary Internal Medicine. 30 : 1305-1312.

Lee SH, Yun SH, Choi E, Park YS, Lee SE, Cho GJ, Kwon OD, Kwak D (2016) Serological detection of Borrelia burgdorferi among horses in Korea. Korean Journal Parasitology 54 : 97-101.

Magnarelli LA, Anderson JF, Shaw E, Post JE, Palka FC (1998) Borreliosis in equids in northeastern United States. American Journal of Veterinary Research 49: 359-362.

Magnarelli LA, Flavell RA, Padula SJ, Anderson JF, Fikrig E (1997) Serologic diagnosis of canine and equine borreliosis: use of recombinant antigens in enzyme-linked immunosorbent assays. Journal of Clinical Microbiology 35: 169-173.

Magnarelli LA, Ijdo JW, Andel AE van, Wu C, Padula SJ, Fikrig E (2000) Serologic confirmation of Ehrlichia equi and Borrelia burgdorferi infections in horses from the northeastern United States. Journal of the American Veterinary Medical Association 217: 1045-1050.

Manion TB, Khan MI, Dinger J, Bushmich SL (1998) Viable Borrelia burgdorferi in the urine of two clinically normal horses. Journal of Veterinary Diagnostic Investigation 10: 196199.

Mast WE, Burrows WM (1976) Erythema chronicum migrans and "lyme arthritis". JAMA $236: 2392$.

Maurizi L, Marié JL, Aoun O, Courtin C, Gorsane S, Chal D, Davoust B (2010) Seroprevalence survey of equine Lyme borreliosis in France and in sub-Saharan Africa. Vector Borne and Zoonotic Diseases 10: 535-537.

Muller I, Khanakah G, Kundi M, Stanek G (2002) Horses and Borrelia: immunoblot patterns with five Borrelia burgdorferi sensu lato strains and sera from horses of various stud farms in Austria and from the Spanish Riding School in Vienna. International Journal of Medical Microbiology 291:80-87.

Pal U, Li X, Wang T, Montgomery RR, Ramamoorthi N, Desilva AM, Bao F, Yang X Pypaert M, Pradhan D, Kantor FS, Telford S, Anderson JF, Fikrig E (2004) TROSPA, an Ixodes scapularis receptor for Borrelia burgdorferi. Cell 119: 457-468.

Passamonti F, Veronesi F, Cappelli K, Capomaccio S, Reginato A, Miglio A, Vardi DM, Stefanetti V, Coletti M, Bazzica C, Pepe M (2015) Polysynovitis in a horse due to Borrelia burgdorferi sensu lato infection--Case study. Annals of Agricultural and Environmental Medicine $22: 247-250$.

Persing DH (1997) The cold zone: a curious convergence of tick-transmitted diseases. Clinical Infectious Diseases 25 :S35S42.

Piesman J, Mather TN, Sinsky RJ, Spielman A (1987) Duration of tick attachment and Borrelia burgdorferi transmission. Journal of Clinical Microbiology 25: 557-558.

Qiu WG, Schutzer SE, Bruno JF, Attie O, Xu Y, Dunn JJ, Fraser CM, Casjens SR, Luft BJ (2004) Genetic exchange and plasmid transfers in Borrelia burgdorferi sensu stricto revealed by three-way genome comparisons and multilocus sequence typing. Proceedings of the National Academy of Sciences of the United States of America 101: 14150-14155.

Schvartz G, Epp T, Burgess HJ, Chilton NB, Lohmann KL (2015a) Comparison between available serologic tests for detecting antibodies against Anaplasma phagocytophilum and Borrelia burgdorferi in horses in Canada. Journal of Veterinary Diagnostic Investigation 27 : 540-546.

Schvartz G, Epp T, Burgess HJ, Chilton NB, Pearl DL, Lohmann KL (2015b) Seroprevalence of equine granulocytic anaplasmosis and lyme borreliosis in Canada as determined by a point-of-care enzyme-linked immunosorbent assay (ELISA). Canadian Veterinary Journal 56 : 575-80.

Stefanciková A, Adaszek Ł, Pet'ko B, Winiarczyk S, Dudinák V (2008) Serological evidence of Borrelia burgdorferi sensu 
lato in horses and cattle from Poland and diagnostic problems of Lyme borreliosis. Annals of Agricultural and Environmental Medicine 15: 37-43.

Sorensen K, DP Neely, Grappell PM, Read W (1990) Lyme disease antibodies in Thoroughbred broodmares, correlation to early pregnancy failure. Journal of Equine Veterinary Science $10: 166-168$.

Stanek G, Gray J, Strle F, Wormser G (2004) Lyme borreliosis. Lancet Infectious Diseases 4: 197-199.

Stanek G, Wormser GP, Gray J, Strle F (2012) Lyme borreliosis. Lancet 379: 461-473.

Steere AC (2006) Lyme borreliosis in 2005, 30 years after initial observations in Lyme Connecticut. Wiener Klinische Wochenschrift 118: 625-633.

Steere AC, Malawista SE, Snydman DR, Shope RE, Andiman WA, Ross MR, Steele FM (1997) Lyme arthritis: an epidemic of oligoarticular arthritis in children and adults in three connecticut communities. Arthritis and Rheumatology 20 : 717.

Stricker RB, Lautin A, Burrascano JJ (2005) Lyme disease: point/counterpoint. Expert Review of Anti-Infective Therapy 3: $155-165$

Thanassi WT, Schoen RT (2000) The lyme disease vaccine: conception, development, and implementation. Annals of Internal Medicine 132: 661-667.
Trevejo RT, Krause PJ, Sikand VK, Schriefer ME, Ryan R, Lepore T, Porter W, Dennis DT (1999) Evaluation of two-test serodiagnostic method for early Lyme disease in clinical practice. Journal of Infectious Diseases 179: 931-938.

Veronesi F, Laus F, Passamonti F, Tesei B, Piergili Fioretti D, Genchi C (2012) Occurrence of Borrelia lusitaniae infection in horses. Veterinary Microbiology $160:$ 535-538.

Wagner B, Freer H, Rollins A, Erb HN, Lu Z, Gröhn Y (2011) Development of a multiplex assay for the detection of antibodies to Borrelia burgdorferi in horses and its validation using Bayesian and conventional statistical methods. Veterinary Immunology and Immunopathology 144 : 374-381.

Wagner B, Goodman LB, Rollins A, Freer HS (2013) Antibodies to OspC, OspF and C6 antigens as indicators for infection with Borrelia burgdorferi in horses. Equine Veterinary Journal $45: 533-537$.

Wang G, Dam AP van, Schwartz I, Dankert J (1999) Molecular typing of Borrelia burgdorferi sensu lato: taxonomic, epidemiological, and clinical implications. Clinical Microbiology Reviews 12: 633-653.

Wodecka B (2003) Detection of Borrelia burgdorferi sensu lato DNA in Ixodes ricinus ticks in North-Western Poland. Annals of Agricultural and Environmental Medicine 10: 171-178. 